\title{
PERENCANAAN PENGELOLAAN PENDAPATAN ASLI DAERAH SEKTOR PAJAK BUMI DAN BANGUNAN PERDESAAN DAN PERKOTAAN DI KABUPATEN BLORA
}

\author{
Robi Nugrahadi \\ Program Studi Magister Ilmu Administrasi Publik, Fakultas Ilmu Administrasi, Universitas Brawijaya, \\ nugrahadirobi@gmail.com \\ Sarwono \\ Program Studi Magister Ilmu Administrasi Publik, Fakultas Ilmu Administrasi, Universitas Brawijaya \\ Riyanto \\ Program Studi Magister Ilmu Administrasi Publik, Fakultas Ilmu Administrasi, Universitas Brawijaya
}

\begin{abstract}
Abstrak
Latar belakang penelitian ini adalah keputusan pemerintah pusat yang melimpahkan kewenangan pengelolaan Pajak Bumi dan Bangunan Perdesaan dan Perkotaan (PBB-P2) dari pusat kepada kabupaten/kota berdasarkan Undang-Undang Nomor 28 Tahun 2009 tentang Pajak Daerah dan Retribusi Daerah. Tujuan dari pelimpahan pengelolaan PBB-P2 tidak lain agar pemerintah kabupaten/kota dapat semakin mandiri dalam hal keuangan daerah, salah satunya dengan mengoptimalkan Pendapatan Asli Daerah (PAD) sektor PBB-P2. Permasalahan yang muncul adalah pemerintah daerah harus menyiapkan beberapa faktor pendukung, diantaranya: sumber daya manusia khususnya penilai PBB-P2, peralatan komputer dan server, sistem operasional dan basis data, ruang pelayanan dan kearsipan yang memadai, serta anggaran yang harus tersedia untuk melaksanakan kegiatan intensifikasi dan ekstensifikasi pajak. Kesiapan faktor pendukung tersebut sangat mempengaruhi tingkat optimalisasi penerimaan PBB-P2. Sesuai kondisi tersebut, penelitian ini bertujuan untuk menganalisis pengelolaan PBB-P2 di Kabupaten Blora sehingga dari hasil analisis tersebut dapat disusun sebuah perencanaan yang bersifat skenario dengan mempertimbangkan kondisi yang tidak pasti di masa depan. Pengumpulan data menggunakan metode Miles, Huberman dan Saldana (2014), sedangkan analisis scenario planning menggunakan metode TAIDA dari Lindgren dan Bandhold (2003). Hasil penelitian ini adalah Pemerintah Kabupaten Blora belum sepenuhnya melaksanakan pengelolaan PBB-P2 secara maksimal. Hal ini berdasarkan fakta empiris bahwa penilai hanya 1 orang yang bertugas melakukan analisis NJOP terhadap lebih dari 500 ribu objek PBB-P2 di Kabupaten Blora. Situasi tersebut menyebabkan penerimaan PBB-P2 tidak sesuai dengan potensi yang sebenarnya.
\end{abstract}

Kata kunci: perencanaan, pendapatan asli daerah.

\begin{abstract}
This research background is property tax management authority transfer by center government to local government according to the laws of local tax number 28 in 2009. The purpose is to make government financial independently and increase local revenue in property tax sector. Problem of that condition is local government must be set up many supporting factors, that is human resources especially property appraisal, computer and server tools, operating system and data base, compatibel files and service room, and exist budget to implement intensification and extensification tax program. Readiness of supporting factors are very influence optimization level of property tax revenue. According that condition, this research purpose is to analyse property tax management in Blora Regency so that from result of analysing can be arrange scenario planning which is consider uncertainty situation in future. Collecting data method of this research use Miles, Huberman, and Saldana method (2014), while scenario planning analysis use TAIDA method from Lindgren and Bandhold (2003). Result of this research is Government of Blora Regency has not maximaly implement property tax management yet. That condition based on empirical fact which is only one man appraisal to analyse NJOP with more than 500 thousand property tax object in Blora Regency. That situation cause property tax revenue not accordance with real potension.
\end{abstract}

Keywords: planning, local revenue. 


\section{PENDAHULUAN}

Pajak merupakan salah satu pendapatan negara yang digunakan untuk membiayai penyelenggaraan pemerintahan dan pembangunan. Tidak seperti kekayaan sumber daya alam yang akan habis pada masanya bila dieksploitasi terus-menerus, sumber penerimaan negara dari sektor pajak akan terus mengalami intensifikasi dan ekstensifikasi objek pajak seiring dengan pertumbuhan ekonomi.

Pajak daerah merupakan salah satu jenis penerimaan kabupaten/kota dalam struktur Pendapatan Asli Daerah (PAD). Berkaitan hal tersebut, dalam rangka optimalisasi PAD dan meningkatkan kemandirian daerah dalam hal keuangan, pemerintah pusat telah menetapkan Undang-Undang Nomor 28 Tahun 2009 Tentang Pajak Daerah dan Retribusi Daerah. Aturan tersebut menggantikan Undang-Undang Nomor 34 Tahun 2000 Tentang Pajak Daerah dan Retribusi Daerah yang dianggap kurang memberikan kepastian hukum kepada daerah untuk melakukan pungutan pajak dan retribusi.

Sebagaimana termaktub dalam Undang-Undang Nomor 28 Tahun 2009, bahwa Pajak Bumi dan Bangunan Perdesaan dan Perkotaan (PBB-P2) merupakan salah satu dari sebelas jenis Pajak Daerah. Pelimpahan PBB-P2 yang sebelumnya merupakan Pajak Pusat dimaksudkan agar penerimaan pendapatan daerah dapat semakin optimal. Secara teknis, PBB-P2 merupakan pajak objektif, dimana kondisi subjek pajak tidak menjadi unsur penghitungan dalam pengenaan PBB-P2 (Hartoyo dan Supardi, 2010:11). Suatu wilayah perkotaan dengan nilai pasar yang tinggi, tentu akan memiliki potensi PBB-P2 yang lebih baik dibandingkan wilayah perdesaan dengan nilai pasar yang rendah karena dasar pengenaan PBB-P2 adalah Nilai Jual Objek Pajak (NJOP). NJOP merupakan harga rata-rata properti pada suatu wilayah, yang terjadi secara wajar antara penjual dan pembeli.

Kabupaten Blora sebagai salah satu daerah kabupaten di Provinsi Jawa Tengah memiliki target PAD Tahun Anggaran 2017 sebesar Rp.190.393.348.000,-. Rincian target PAD tersebut digambarkan sebagai berikut:

Diagram 1. Target PAD Kabupaten Blora Tahun 2017

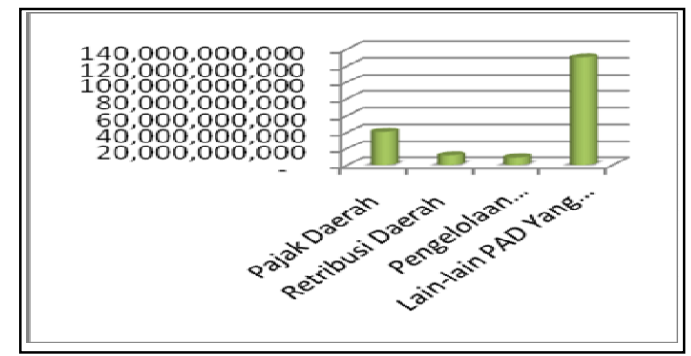

Sumber : BPPKAD Kabupaten Blora, 2017.
Lain-lain PAD yang sah menjadi target penerimaan tertinggi sebesar Rp.129.796.813.000,disusul pajak daerah sebesar Rp.40.508.366.000,-. Urutan ketiga retribusi daerah sebesar Rp.11.248.169.000,diikuti pengelolaan kekayaan daerah yang dipisahkan dengan target sebesar Rp.8.840.000.000,-.

Berdasarkan penelitian pendahuluan, data target dan realisasi PBB-P2 Kabupaten Blora selama tiga tahun terakhir disajikan dalam diagram sebagai berikut:

Diagram 2. Target dan Realisasi PBB-P2

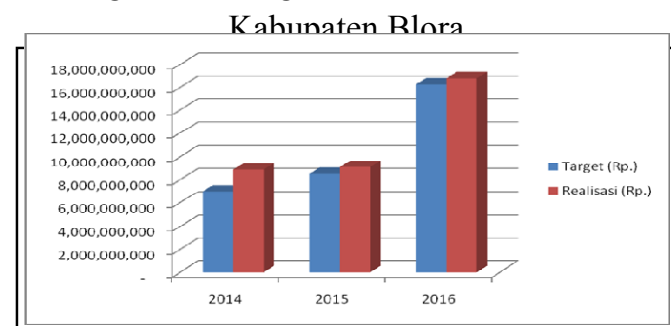

Sumber : BPPKAD Kabupaten Blora, 2017.

Kabupaten Blora menetapkan target PBB-P2 tahun 2014 sebesar Rp.7.000.000.000,- dan memperoleh realisasi sebesar Rp.8.875.741.446,- atau 126,8\%. Terdapat kenaikan penerimaan PBB-P2 yang sangat signifikan antara tahun 2015 dan 2016, yaitu semula dengan target sebesar Rp.8.500.000.000,- dan realisasi Rp.9.100.803.392,- (107,07\%) pada tahun 2015 ditetapkan target sebesar Rp.16.250.000.000,- dan realisasi Rp.16.773.227.257,- (103,22\%) pada tahun 2016. Kenaikan tersebut disebabkan adanya proses kenaikan klas NJOP bumi dengan tujuan agar besaran NJOP bumi semakin mendekati nilai pasar. Melalui data tersebut, terlihat bahwa realisasi PBB-P2 selama tiga tahun terakhir selalu melebihi target yang ditetapkan, sedangkan data pokok ketetapan dan realisasi pokok PBB-P2 selama tiga tahun terakhir menunjukkan hasil yang berbeda, yaitu:

Diagram 3. Pokok Ketetapan dan Realisasi Pokok PBB-P2 Kabupaten Blora

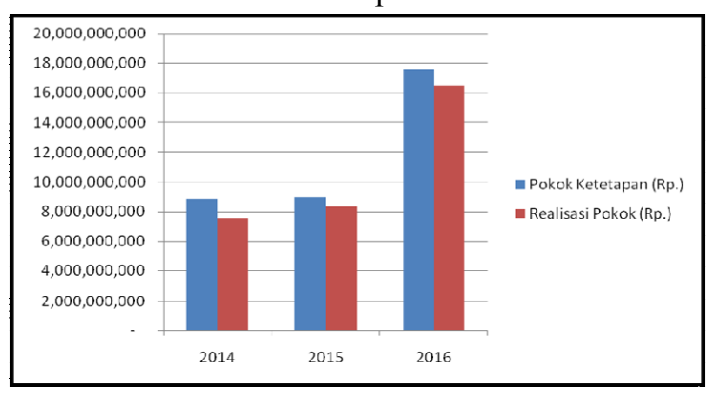

Sumber: BPPKAD Kabupaten Blora, 2017.

Realisasi PBB-P2 pada satu tahun pajak terdiri dari realisasi pokok ketetapan tahun berjalan dan realisasi tunggakan tahun sebelumnya. Setelah data realisasi dipisahkan, maka terlihat pada tahun 2014 dari pokok ketetapan sebesar Rp.8.848.642.059,- diperoleh realisasi 
sebesar Rp.7.575.037.922,-. Demikian juga tahun 2015 dengan pokok ketetapan Rp.8.995.912.592,- terdapat realisasi Rp.8.291.083.916,- dan tahun 2016 pokok ketetapan Rp.17.576.327.281,- realisasinya sebesar Rp.16.464.077.974,-.

Berdasarkan sajian data tersebut, dapat disimpulkan bahwa realisasi total PBB-P2 dalam satu tahun pajak selalu melebihi target penerimaan yang telah ditetapkan, sedangkan realisasi pokok tidak pernah mencapai $100 \%$ dari pokok ketetapan dalam tiga tahun terakhir. Hal ini berarti terdapat perbedaan besaran pokok ketetapan dan target PBB-P2. Terdapat selisih antara besaran pokok ketetapan PBB-P2 dan besaran target yang ditetapkan oleh BPPKAD Kabupaten Blora, dimana target yang direncanakan selalu lebih rendah dari besaran ketetapan PBB-P2. Target terendah ditetapkan 79,11\% dari pokok ketetapan pada tahun 2014 dan tertinggi 94,49\% dari pokok ketetapan pada tahun 2015. Perbedaan ini menunjukkan bahwa target yang ditetapkan tidak sesuai dengan potensi yang sebenarnya.

Melihat permasalahan dalam pengelolaan PBB-P2 di Kabupaten Blora, maka diperlukan sebuah perencanaan yang baik untuk melakukan analisis potensi penerimaan PBB-P2. Demi tujuan tersebut, peneliti akan melakukan analisis perencanaan pengelolaan PBB-P2 menggunakan metode scenario planning (Lindgren dan Bandhold: 2013) agar diperoleh konsep strategi yang tepat untuk optimalisasi penerimaan PBB-P2. Metode scenario planning dapat menentukan 2 faktor penggerak terkuat yang akan menjadi titik acuan dalam mendeskripsikan strategi-strategi untuk mencapai tujuan yang direncanakan. Penelitian ini diharapkan dapat menjadi referensi bagi peneliti selanjutnya untuk melakukan penelitian lebih dalam tentang PBB-P2 dan dapat menjadi rekomendasi bagi pemerintah daerah untuk meningkatkan penerimaan PAD dari sektor PBB-P2.

\section{METODE}

Penelitian ini menggunakan pendekatan kualitatif dengan metode pengumpulan data menggunakan teknik observasi partisipasi aktif dan depth interview. Sumber data berasal dari wawancara terhadap narasumber maupun pengumpulan dokumen. Teknik wawancara adalah purposive sampling sehingga benar-benar diperoleh data yang valid dan reliable berasal dari orang-orang yang ahli dalam bidang PBB-P2. Penelitian ini memilih lokasi di Badan Pendapatan Pengelolaan Keuangan dan Aset Daerah (BPPKAD) Kabupaten Blora sebagai unit organisasi yang mengelola PBB-P2. Oleh karena itu, informan dalam penelitian ini yaitu Kepala BPPKAD, Kabid Pendapatan BPPKAD, Kasubid Pendapatan BPPKAD, serta staf pelaksana yang memiliki tugas mengelola PBB-P2. Penelitian dilaksanakan selama 6 bulan.

\section{HASIL DAN PEMBAHASAN}

\section{Pengelolaan PBB-P2 di Kabupaten Blora}

Sesuai hasil penelitian di lokasi, bagian pendaftaran pendataan dan penilaian adalah bagian awal dari sebuah pengelolaan PBB-P2. Pendaftaran merupakan kegiatan aktif wajib pajak untuk mendatangi tempat pelayanan dengan tujuan melakukan pendaftaran objek pajak yang dimiliki atau dikuasainya. Dalam hal ini petugas pajak akan melakukan verifikasi berkas pendaftaran baik verifikasi administrasi maupun verifikasi lapangan. Berbeda dengan pendaftaran, pendataan merupakan kegiatan aktif petugas pajak untuk mengumpulkan data objek pajak sekaligus verifikasi di lokasi, tanpa menunggu permohonan pendaftaran dari wajib pajak. Demikian juga penilaian, dapat disebut sebagai kegiatan menghitung dan menganalisis nilai pasar sebidang tanah dan/atau bangunan dengan tujuan untuk menentukan besarnya dasar pengenaan PBB-P2. Fungsi penilaian menjadi satu hal yang sangat pokok diperlukan dalam pengelolaan PBB-P2. Ketetapan PBB-P2 berasal dari perkalian tarif dan NJOP, sedangkan NJOP dirumuskan berdasarkan hasil kegiatan penilaian terhadap objek pajak. Oleh karena itu, penilaian harus dilakukan oleh orang yang sangat berkompeten di bidang penilaian properti. Terkait penilaian, TR sebagai Kepala Sub Bidang Pendaftaran, Pendataan, dan Penilaian menyatakan "penilaian masih sedikit yang bisa dilakukan karena petugas penilai cuma 1 orang, sedangkan potensi PBB disini cukup besar" (wawancara 14 Agustus 2017).

Terhitung sejak pelimpahan PBB-P2 dari pajak pusat menjadi pajak daerah, BPPKAD Kabupaten Blora telah melaksanakan kegiatan pendataan dan penilaian sebagai bagian dari updating data objek pajak. Berdasarkan data yang diperoleh peneliti, BPPKAD telah melakukan penilaian secara individu terhadap objek pajak khusus atau bernilai tinggi sesuai petunjuk Peraturan Bupati Blora Nomor 26 Tahun 2013, terdiri dari:

a) Hotel : 4 unit;

b) Pabrik : 3 unit;

c) SPBE : 2 unit;

d) Rumah karaoke: 1 unit;

e) Koperasi: 1 unit;

f) Gudang: 2 unit.

Selain itu, sebanyak ribuan objek pajak baik kolektif tingkat desa maupun perorangan telah dilakukan perubahan sesuai permohonan dari perangkat desa maupun langsung perorangan dari wajib pajak. Hal ini 
berdasarkan wawancara peneliti dengan seorang petugas input data BPPKAD Kabupaten Blora, RP:

“...dulu tahun 2014 saya menghitung dalam satu tahun permohonan perubahan sudah lebih dari 4.000 objek pajak setahun, karena satu perangkat desa bisa mengajukan sampai dua ratus objek pajak, begitu juga tahun berikutnya malah semakin meningkat jumlahnya. Sayang sekali aplikasi SISMIOP ini tidak ada menu untuk menghitung riwayat perubahan SPPT, jadi angkanya hanya perkiraan dari formulir permohonan yang masuk" (wawancara 14 Agustus 2017).

Menyimpulkan hasil wawancara di atas, berarti aplikasi SISMIOP sebagai operating system PBB-P2 tidak dapat digunakan untuk menelusuri berapa banyak perubahan balik nama, pemecahan, penggabungan, maupun penghapusan yang telah dilakukan. Riwayat asal SPPT juga tidak dapat ditelusuri apabila terjadi kasus sengketa tanah di masyarakat. Terkait objek khusus PBBP2 yang telah dinilai oleh BPPKAD, lebih lanjut DH sebagai petugas pemeliharaan SISMIOP menyatakan:

“...masih banyak objek non standar yang belum dinilai karena penilai PBB-P2 cuma satu orang, sedangkan proses penilaian satu objek memerlukan waktu lebih dari satu minggu. Misalnya tower telekomunikasi yang belum dinilai sama sekali sampai saat ini. Padahal jumlahnya lebih dari seratus tower se-Kabupaten Blora" (wawancara 17 Agustus 2017).

Pernyataan narasumber tersebut didukung oleh data terakhir menara telekomunikasi yang telah berijin dan beroperasi di wilayah Blora yaitu sebanyak 139 tower, sedangkan hanya 24 unit diantaranya yang sudah dinilai.

\section{Tracking}

Sebagai tahap pertama dari metode TAIDA, tracking digunakan untuk melacak perubahan kondisi lingkungan yang terjadi atau trend yang dapat mempengaruhi keadaan di masa depan. Trend ini disusun berdasarkan hasil obervasi dan wawancara dengan narasumber serta dihubungkan dengan kondisi eksisting pengelolaan PBB-P2 di Kabupaten Blora saat ini. Hasilnya akan diperoleh sebuah faktor yang mempengaruhi perubahan yang disebut driving force.

Data realisasi PBB-P2 pada tiga tahun terakhir sejak dikelola oleh Pemerintah Daerah Kabupaten Blora menunjukkan bahwa peluang yang ada belum dapat dioptimalkan untuk meningkatkan PAD. Hal ini diperkuat oleh pernyataan Kasubid Pendataan dan Penilaian, TR "peluang penerimaan dari sektor PBB sebenarnya cukup besar, tetapi kami hanya punya satu orang penilai untuk menghitung NJOP dan mendata begitu banyak objek" (wawancara 8 September 2017).

Berdasarkan hasil wawancara, peneliti menyimpulkan beberapa trend yang dapat mempengaruhi pengelolaan PBB-P2 di Kabupaten Blora, yaitu politik, ekonomi, teknologi dan sosial. Selanjutnya peneliti akan menentukan driving force yang berperan sebagai variabel utama pada tahap analysing.

\section{Analysing}

Pada tahap analysing ini, proses penyusunan skenario mulai dilakukan. Sebelum menyusun sebuah skenario, terlebih dahulu akan dilakukan proses identifikasi terhadap variabel utama trend yang paling mempengaruhi situasi ketidakpastian dan dampaknya untuk kondisi di masa mendatang. Sebagai alat untuk memetakan dampak dari trend, maka harus dibuat analisis cross impact. Fungsi analisis cross impact adalah untuk melihat saling keterkaitan antara trend-trend yang ada dan mempersempit cakupan driving force sehingga dapat memunculkan strongest driver dan strongest dependent sebagai faktor yang terkuat.

Tabel 1. Cross Impact Analysis

\begin{tabular}{|c|c|c|c|c|c|}
\hline $\begin{array}{l}\text { Variabel } \\
\text { Trend }\end{array}$ & Politik & Ekonomi & Teknologi & Sosial & $\begin{array}{l}\text { Total } \\
\text { Driver }\end{array}$ \\
\hline 1. Politik & & 2 & -1 & 1 & 4 \\
\hline 2. Ekonomi & -2 & & 1 & -2 & $\begin{array}{c}5 \\
\text { Strongest } \\
\text { Driver }\end{array}$ \\
\hline 3. Teknologi & -2 & -1 & & 1 & 4 \\
\hline 4. Sosial & -2 & 1 & 1 & & 4 \\
\hline $\begin{array}{c}\text { Total } \\
\text { Dependent }\end{array}$ & $\begin{array}{c}6 \\
\text { Strongest } \\
\text { Dependent }\end{array}$ & 4 & 3 & 4 & \\
\hline
\end{tabular}

Sumber: Peneliti, diolah (2017)

Strongest driver adalah faktor penggerak terkuat diantara faktor penggerak yang lain, sedangkan strongest dependent adalah faktor ketergantungan terbesar diantara faktor yang lain. Dengan tabel cross impact analysis di atas, dapat diketahui trend ekonomi menjadi faktor penggerak terkuat dan trend politik menjadi faktor ketergantungan terbesar. Trend ekonomi menjadi faktor penggerak utama dalam pengelolaan PBB-P2 dimana kemampuan ekonomi masyarakat berbanding lurus 
dengan tingkat kepatuhan atau pelunasan kewajiban perpajakan. Sedangkan trend politik menjadi ketergantungan terbesar dimana komitmen pemerintah untuk meningkatkan pendapatan PBB-P2 sangat tergantung dengan tingkat pertumbuhan ekonomi masyarakat. Trend ekonomi terdiri dari beberapa faktor penggerak, yaitu pertumbuhan ekonomi, kemajuan investasi, jual beli properti, pembangunan perumahan, pengembangan industri dan pariwisata. Sedangkan trend politik berupa komitmen pemerintah, regulasi, manajemen Sumber Daya Manusia (SDM) pengelola PBB-P2, ketersediaan anggaran, keterbukaan informasi, sarana/prasarana, pembangunan fasilitas umum, koordinasi, updating data, penilai PBB, pemetaan, penilaian objek pajak, analisis NJOP, dan diklat SDM. Selain hal itu, terdapat trend teknologi berupa sistem informasi teknologi dan trend sosial, yaitu, kemampuan wajib pajak dan kepatuhan wajib pajak.

Hasil cross impact analysis kemudian akan diplotting dalam diagram cross impact sehingga semakin jelas posisi tiap driving force. Driving force digambarkan dalam sumbu $\mathrm{X}$ dan dependent factor dalam sumbu $\mathrm{Y}$. Berikut diagram cross impact:

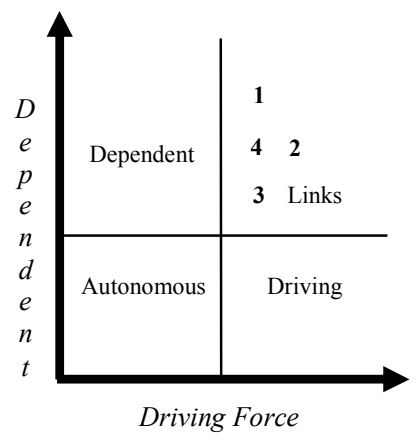

Sumber: Peneliti, diolah (2017)

Gambar 1. Diagram Cross Impact

Berdasarkan cross impact analysis diperoleh hasil faktor penggerak terkuat adalah trend ekonomi sedangkan faktor ketergantungan terbesar dalah trend politik, sehingga peneliti akan memilih dua faktor driving force yang memiliki pengaruh paling kuat dan dapat menyebabkan terjadinya kondisi yang tidak menentu di masa depan. Kedua faktor tersebut adalah komitmen pemerintah dan pertumbuhan ekonomi. Kemudian dengan kedua uncertainty factor atau driving force terkuat tersebut, peneliti akan membuat diagram cross scenario yang menghasilkan empat skenario. Kedua faktor utama, yaitu komitmen pemerintah dan pertumbuhan ekonomi akan menjadi dua sumbu yaitu $\mathrm{X}$ dan Y sehingga muncul empat kuadran skenario dengan karakteristik yang berbeda. Diagram cross scenario perencanaan pengelolaan PBB-P2 di Kabupaten Blora, sebagai berikut:

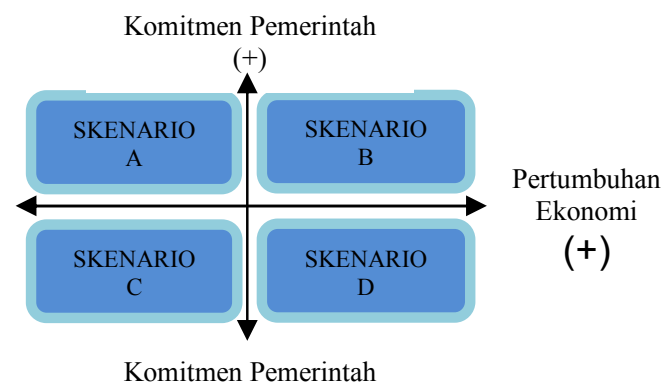

$(-)$

Sumber: Hasil Penelitian, diolah (2017)

Gambar 2. Diagram Cross Scenario

Diagram cross scenario di atas membagi empat skenario perencanaan pengelolaan PBB-P2 dalam kuadran yang berbeda. Penjelasan skenario tersebut adalah:

(a) Skenario A (Komitmen Pemerintah + Pertumbuhan Ekonomi -)

Komitmen tinggi pemerintah seringkali tidak mendapatkan dukungan dari situasi sosial maupun ekonomi. Pemerintah merencanakan target yang tinggi pada penerimaan sektor PBB-P2, tetapi kondisi ekonomi masyarakat sedang lesu. Tingginya inflasi mempengaruhi motivasi belanja masyarakat. Dalam skenario ini, pemerintah telah memberikan kebijakan paling maksimal, yaitu:

(1) Tidak menerapkan sanksi denda $2 \%$ per bulan bagi pembayaran yang lewat jatuh tempo;

(2) Melaksanakan sosialisasi secara intensif ke desadesa;

(3) Memberikan pelayanan secara cepat dan tepat waktu;

(4) Memberikan insentif pelunasan bagi desa/kelurahan yang lunas sebelum jatuh tempo;

(5) Memberikan keringanan PBB-P2 bagi warga yang tidak mampu;

(6) Membuka akses jalan, jembatan, dan membangun taman kota untuk memancing investor.

Kemampuan ekonomi masyarakat yang stagnan atau bahkan menurun mempengaruhi trend pelunasan PBB-P2. Komitmen tinggi pemerintah melalui kebijakan yang positif bagi masyarakat juga tidak mampu meningkatkan penerimaan PBB-P2. Hal ini dipengaruhi oleh naiknya harga kebutuhan pokok, hasil panen yang semakin berkurang karena perubahan cuaca secara ekstrim sehingga pendapatan masyarakat secara umum menurun. Akibatnya tunggakan pajak semakin besar karena pendapatan 
masyarakat yang turun, menyebabkan ketidakmampuan dalam membayar pajak.

(b) Skenario B (Komitmen Pemerintah + Pertumbuhan Ekonomi + )

Dalam skenario B ini, pemerintah memiliki komitmen yang tinggi untuk meningkatkan PAD dari sektor PBB-P2. Komitmen pemerintah dalam skenario B ini bersifat positif yang artinya memberikan dukungan bagi terlaksananya pengelolaan PBB-P2 yang optimal. Skenario kebijakan maupun program kerja pemerintah diantaranya:

(1) Melaksanakan amanat regulasi, diantaranya melakukan updating data melalui kegiatan analisis NJOP, pemetaan, dan penilaian objek pajak secara teratur sesuai perkembangan wilayah;

(2) Menyediakan anggaran setiap tahun untuk peningkatan kompetensi SDM melalui keikutsertaan diklat PBB-P2, pemeliharaan peralatan komputer dan software, serta pembangunan pengelolaan pajak yang bersifat online untuk mewujudkan keterbukaan informasi publik;

(3) Melakukan penataan SDM dengan baik sesuai dengan kebutuhan tugas masing-masing, yaitu petugas pendata dan penilai, petugas pelayanan, admin server, petugas penagihan, serta petugas pelaporan;

(4) Berkoordinasi dengan unit organisasi terkait, misalnya Dinas Perijinan untuk koneksi data terkait Ijin Mendirikan Bangunan sehingga bangunan yang telah berdiri dapat segera ditindaklanjuti untuk dilakukan pendataan dan penilaian;

(5) Menyediakan ruang pelayanan yang lebih compatibel agar pelayanan dapat belangsung cepat dan memberikan kenyamanan kepada wajib pajak;

(6) Membangun fasilitas umum berupa lampu penerangan jalan dan akses jalan yang baik untuk daerah pinggiran sehingga memancing investor untuk melakukan pembangunan berupa perumahan, kawasan industri maupun pariwisata;

(7) Menjalin kerja sama dengan kejaksaan untuk melakukan penindakan hukum bagi petugas pemungut desa/kelurahan yang terbukti melakukan korupsi setoran PBB-P2.

Di samping komitmen pemerintah yang bersifat positif, aspek pertumbuhan ekonomi juga mengalami peningkatan. Hal ini ditandai dengan banyaknya pendirian kawasan perumahan, hotel, industri, serta pariwisata yang selalu dipenuhi pengunjung. Banyaknya pembangunan properti tersebut memberikan peluang bagi pemerintah daerah untuk melakukan penilaian NJOP secara presisi dan objektif sehingga penerimaan PBB-P2 dapat meningkat.

(c) Skenario C (Komitmen Pemerintah - Pertumbuhan Ekonomi -)

Skenario C menempatkan pada situasi yang paling tidak menguntungkan, yaitu komitmen pemerintah negatif dan pertumbuhan ekonomi juga negatif. Model pengelolaan PBB-P2 tidak mengalami inovasi atau perbaikan karena pemerintah tidak concern pada hal itu, tetapi indikator keberhasilan hanya pada pemenuhan target penerimaan pajak secara umum. Tidak ada persiapan anggaran untuk belanja diklat pegawai, pengadaan sarana/prasarana, perawatan peralatan, maupun anggaran koordinasi dengan instansi lain. Tidak ada pembangunan kawasan industri maupun pariwisata, pengembang perumahan pun mempertimbangkan kembali untuk membangun perumahan karena faktor daya beli masyarakat yang menurun. Kondisi ekonomi yang menurun tidak akan terjadi apabila komitmen pemerintah cukup tinggi untuk menginisiasi dalam bentuk kebijakan yang dapat mengundang investor masuk ke wilayah Blora. Perekonomian masyarakat Blora akan naik secara bertahap apabila ada dukungan dari pemerintah dan private sector.

(d) Skenario D (Komitmen Pemerintah - Pertumbuhan Ekonomi + )

Kondisi yang tidak menentu pada aspek birokrasi dapat menyebabkan pengelolaan pajak daerah menjadi kurang optimal, padahal sektor ekonomi sedang mengalami pertumbuhan yang baik. Hal ini dapat terjadi pada skenario D. Pemerintah daerah lebih mengutamakan pendapatan daerah dari sektor yang lain daripada mengoptimalkan PBB-P2. Akibatnya program dan kegiatan yang disusun tidak mendukung pada peningkatan penerimaan PBB-P2.. Secara umum, apabila komitmen pemerintah rendah dalam mengelola PBB-P2, maka dapat berakibat:

(1) Terhambatnya upaya pemetaan, analisis NJOP dan updating data objek pajak;

(2) Munculnya complain dari masyarakat yang merasa tidak adil dikenakan PBB-P2, dibandingkan tetangga sebelahnya;

(3) NJOP menjadi tidak seimbang antar wilayah karena pertumbuhan ekonomi yang pesat menciptakan daerah bisnis baru, sedangkan upaya pemetaan ulang tidak dilakukan oleh pemerintah;

(4) Pelayanan kepada masyarakat tidak optimal, pelayanan masih bersifat konvensional, tidak ada anggaran untuk membangun pelayanan berbasis internet; 
(5) Hilangnya potensi penerimaan PBB-P2 karena tidak ada upaya koordinasi dengan unit organisasi atau instansi lain;

(6) Tidak ada ketertarikan investor untuk berinvestasi di wilayah Kabupaten Blora karena pemerintah belum menyediakan sarana fasilitas umum, misalnya lampu penerangan jalan, jembatan penghubung antar desa, jalan raya yang berkualitas, serta fasilitas lain yang seharusnya dapat memancing tumbuhnya private sector.

Rendahnya komitmen pemerintah tersebut berbanding terbalik dengan indikator pertumbuhan ekonomi. Walaupun pemerintah belum maksimal menyediakan sarana fasilitas umum, tetapi sektor swasta masih ada yang peduli dengan mendirikan perumahan bersifat cluster atau satu pintu. Hal ini didasari kebutuhan tempat tinggal sebagai kebutuhan paling utama dan cukup banyak pegawai di instansi Kabupaten Blora yang merupakan warga pendatang. Artinya banyak warga pendatang dengan penghasilan yang mencukupi kemudian membeli perumahan baru untuk menciptakan kenyamanan tinggal di wilayah Blora. Skenario D merupakan kondisi terbalik antara komitmen pemerintah yang negatif dan pertumbuhan ekonomi yang positif. Kondisi seperti ini menyebabkan potensi pajak yang hilang menjadi semakin besar dan hal ini menjadi kerugian bagi daerah sendiri.

\section{Imaging}

Tahap imaging memberikan penekanan pada perumusan visi, tentunya visi yang bersifat jangka panjang. Visi yang disusun mengacu pada skenarioskenario yang telah dipetakan sebelumnya. Tujuan dari perumusan visi adalah memberikan sebuah fokus masa depan sehingga dapat diuraikan strategi-strategi untuk mewujudkan visi tersebut.

Disebutkan dalam situs resmi Pemerintah Kabupaten Blora, visi Kabupaten Blora adalah:

\section{"Terwujudnya Masyarakat Blora Yang Lebih Sejahtera Dan Bermartabat"}

PBB-P2 secara tidak langsung mendukung tercapainya visi Kabupaten Blora, apabila diterapkan secara adil dan seimbang. Hasil pungutan pajak daerah dikelola dalam satu rekening yaitu kas daerah. Selanjutnya kas daerah tersebut dianggarkan untuk program kegiatan pemerintah yang pro rakyat, diantaranya subsidi pendidikan dasar, jaminan kesehatan masyarakat, penyuluhan keluarga berencana, bedah rumah, pembangunan infrastruktur, pelatihan tenaga kerja, serta kegiatan lain yang bersifat produktif bagi masyarakat.
BPPKAD Kabupaten Blora selaku pengelola PBB-P2 memiliki visi:

"Mewujudkan Institusi Pengelolaan Keuangan Dan Aset Daerah Yang Profesional, Tertib, Transparan, Akuntabel, Dan Kredibel"

Tentunya visi BPPKAD Kabupaten Blora harus didukung dengan rencana program kegiatan yang sesuai agar visi tersebut dapat tercapai. Dalam konteks pengelolaan PBB-P2, visi di atas kurang fokus untuk dijadikan sebagai acuan strategi ke depan. Oleh karena itu, peneliti merumuskan visi baru sesuai dengan perencanaan pengelolaan PAD sektor PBB-P2 di Kabupaten Blora, yaitu:

\section{"Terwujudnya Pengelolaan Pajak Bumi dan \\ Bangunan Perdesaan dan Perkotaan \\ Yang Transparan, Akuntabel dan Adil Demi Kesejahteraan Masyarakat Blora"}

Visi tersebut diharapkan dapat menjadi lokomotif terciptanya strategi-strategi pemungutan PBBP2 secara optimal dan pengelolaan pajak daerah yang profesional secara umum. Dengan adanya visi baru, langkah selanjutnya dalam scenario planning adalah deciding.

\section{Deciding}

Deciding atau memutuskan adalah tahapan dimana strategi-strategi mulai dirumuskan dengan berpedoman pada visi baru yang telah disusun. Penyusunan strategi dilakukan dengan mempertimbangkan segala informasi yang berkaitan serta mengidentifikasi pilihan-pilihan yang mungkin untuk dilaksanakan dalam jangka panjang. Strategi yang dimaksud berupa penjabaran misi yang akan dijalankan untuk mencapai atau mendukung visi yang telah dicanangkan.

Maka dengan adanya visi baru "terwujudnya pengelolaan pajak bumi dan bangunan perdesaan dan perkotaan yang transparan, akuntabel dan adil demi kesejahteraan masyarakat blora", peneliti merumuskan misi baru, sebagai berikut:

(1) Memperkuat basis data dan sistem pengelolaan PBB-P2 untuk memberikan pelayanan yang optimal kepada masyarakat;

(2) Meningkatkan kompetensi petugas pengelola PBB-P2 demi akuntabilitas pengelolaan PBB-P2;

(3) Aktif berkoordinasi dengan instansi maupun unit organisasi lain untuk meningkatkan realisasi PBB-P2;

(4) Meningkatkan tata kelola PBB-P2 melalui pembangunan pengelolaan $\mathrm{PBB}-\mathrm{P} 2$ berbasis online; 
(5) Penyediaan sarana/prasarana pendukung demi efektifitas kegiatan pendataan, penetapan, dan penagihan PBB-P2.

Kelima misi tersebut masih bersifat umum dan tentunya harus diperinci dalam bentuk strategi-strategi sehingga mudah dalam pelaksanaan teknis dan evaluasinya. Penjabaran strategi sebagai berikut:

Misi 1 : Memperkuat basis data dan sistem pengelolaan PBB-P2 untuk memberikan pelayanan yang optimal kepada masyarakat.

Upaya yang harus dilakukan untuk mewujudkan misi 1, yaitu:

(1) Melakukan identifikasi dan analisis transaksi jual beli dari sumber penjual atau pembeli secara langsung, pengembang perumahan, iklan di surat kabar maupun media massa online, serta data pembayaran Bea Perolehan Hak Atas Tanah dan Bangunan (BPHTB);

(2) Melakukan analisis dan pemetaan NJOP bumi sesuai dengan tingkat perkembangan wilayah per zona, apabila perlu akan dibuat zona nilai tanah baru atau pemekaran zona;

(3) Melakukan penilaian secara individual terhadap objek pajak khusus yang baru berdiri dan sudah beroperasi, penilaian bangunan menggunakan harga material yang sudah disesuaikan;

(4) Menggandakan basis data untuk disimpan di harddisk yang terpisah sebagai langkah pengamanan dari virus komputer;

(5) Melakukan editing peta lokasi sesuai kondisi terbaru, sehingga memudahkan untuk mengidentifikasi sebuah lokasi atau melakukan analisis NJOP bumi;

(6) Pemetaan wajib pajak berdasarkan besaran ketetapan PBB-P2 dari skala besar, menengah, dan kecil. Misalnya wajib pajak besar dengan ketetapan di atas 1 juta rupiah, menengah Rp.100.000,sampai dengan Rp.1.000.000,- dan kecil di bawah Rp.100.000,-. Hal ini untuk memudahkan menyusun skala prioritas penagihan berdasarkan potensi realisasinya.

Indikator keberhasilan:

tersedianya data objek pajak dan wajib pajak yang akurat, objektif, dan presisi sehingga mempermudah pelayanan kepada wajib pajak.

Misi 2 : Meningkatkan kompetensi petugas pengelola PBB-P2 demi akuntabilitas pengelolaan PBB-P2.

Upaya peningkatan kompetensi petugas pengelola PBB-P2 dilakukan dengan cara:

(1) Mengikutsertakan pegawai Pemerintah Kabupaten Blora yang masih memenuhi syarat dari aspek usia maupun kepangkatan untuk menempuh perkuliahan di bidang penilaian PBB-P2 atau penilaian properti. Pilihan jenjang kuliah adalah DIII Penilaian PBB, S1 Perpajakan, atau S2 Penilaian Properti. Pembiayaan dibebankan pada APBD Kabupaten Blora.

(2) Mengadakan diklat penilaian PBB-P2 dengan cara mengundang vendor swasta penyedia jasa pelatihan untuk datang ke Kabupaten Blora dan melatih secara langsung petugas di lapangan;

(3) Mengikutsertakan petugas pengelola PBB-P2 dalam bimbingan teknis yang diadakan oleh Direktorat Jenderal Pajak Kementerian Keuangan Republik Indonesia;

Indikator keberhasilan:

tersedianya tenaga pengelola PBB-P2 yang handal dan cakap untuk melaksanakan tugas serta memiliki integritas yang tinggi terhadap instansi.

Misi 3 : Aktif berkoordinasi dengan instansi maupun unit organisasi lain untuk meningkatkan realisasi PBB-P2.

Koordinasi dengan unit organisasi maupun instansi lain sangat penting untuk dilakukan dan hal ini berdasarkan penelitian masih sangat kurang untuk dilaksanakan. Peneliti mendeskripsikan beberapa fungsi koordinasi dengan unit organisasi:

(a) Ditjen Pajak Kementerian Keuangan Republik Indonesia

Koordinasi dengan Ditjen Pajak adalah untuk meminta pelatihan dalam bidang penilaian PBB-P2 atau pendampingan dari petugas KPP Pratama untuk menyelesaikan updating data objek pajak. Ditjen Pajak juga perlu mempertimbangkan penyaluran lulusan sekolah kedinasan di bidang penilaian PBB untuk ditempatkan di Kabupaten Blora.

(b) Lembaga Perguruan Tinggi

Kerja sama dengan lembaga perguruan tinggi diperlukan untuk melakukan penggambaran peta sesuai kondisi terkini dengan menggunakan sistem informasi teknologi. Pakar di bidang Geodesi sangat dibutuhkan untuk analisis seputar ilmu pertanahan.

(c) Pemerintah Kabupaten/Kota

Fungsi koordinasi dengan pemerintah kabupaten/kota adalah menyelaraskan dan menyeimbangkan NJOP terutama dengan wilayah pemerintah kabupaten/kota yang bersebelahan. Apabila terjadi ketimpangan yang besar di daerah perbatasan dalam pemungutan PBB-P2 padahal karakteristik tanah sama, hal ini akan menimbulkan protes atau keberatan dari masyarakat. Berlaku pula untuk pemungutan objek berskala nasional, misalnya menara telekomunikasi atau tower.

(d) Dinas Perijinan 
Dinas Perijinan memiliki tugas melakukan verifikasi dan menerbitkan beberapa macam ijin usaha, diantaranya ijin usaha perdagangan dan ijin mendirikan bangunan. Data yang dimiliki Dinas Perijinan sangat penting untuk ditindaklanjuti oleh BPPKAD dengan kegiatan pendataan dan penilaian. Oleh karena itu, koneksi data dengan Dinas Perijinan harus dibangun dengan baik.

(b) Kecamatan

Camat sebagai pemegang wilayah, bertanggung jawab langsung kepada kepala daerah. Hal ini juga berlaku untuk pemungutan PBB-P2. BPPKAD harus memiliki koordinasi yang baik dengan kecamatan.

(c) Kelurahan/Desa

Level paling bawah dalam pengelolaan PBBP2 adalah kelurahan/desa, tetapi berdasarkan observasi lapangan penyetoran PBB-P2 dari desa/kelurahan sering terlambat, bahkan di daerah tertentu masih memiliki tunggakan yang cukup besar. Kendala seperti ini harus cepat diselesaikan, BPPKAD harus melakukan pemetaan terkait tunggakan PBB-P2, apakah wajib pajak belum membayar atau wajib pajak membayar melalui petugas desa/kelurahan tetapi uangnya belum disetorkan ke rekening kas daerah.

Indikator keberhasilan:

terwujudnya koordinasi yang baik antar instansi sehingga memperlancar transfer data dan informasi untuk optimalisasi PBB-P2.

Misi 4 : Meningkatkan tata kelola PBB-P2 melalui pembangunan pengelolaan $\mathrm{PBB}-\mathrm{P} 2$ berbasis online.

Wajib pajak tidak harus datang langsung ke tempat pelayanan untuk mendapatkan jasa pelayanan, karena data yang dibutuhkan oleh petugas pajak dapat dikirimkan melalui internet. Berkas KTP, sertifikat, ijin mendirikan bangunan, maupun SPPT PBB-P2 dapat di-scan kemudian dikirimkan ke BPPKAD untuk dilakukan verifikasi. Petugas Unit Pelaksana Teknis bersama petugas desa atau kelurahan melakukan verifikasi lapangan. Setelah mendapatkan hasil verifikasi, petugas BPPKAD akan mengirimkan kembali hasil verifikasi dan SPPT PBB-P2 hasil perubahan atau pendaftaran kepada wajib pajak. Bank tempat pembayaran mendapatkan surat tembusan hasil verifikasi.

Model pelayanan tersebut dapat dikategorikan dalam perspektif new public service, dimana setiap warga negara disamping memiliki hak untuk berpartisipasi dalam penyelenggaraan negara dan mendapatkan pelayanan yang prima dari pemerintah, juga memiliki kewajiban untuk membayar pajak. Inilah yang disebut teori democratic citizenship.

Indikator keberhasilan:

terciptanya kemudahan pelayanan bagi masyarakat sehingga meningkatkan kesadaran untuk membayar pajak.

Misi 5 : Penyediaan sarana/prasarana pendukung demi efektifitas kegiatan pendataan, penetapan, dan penagihan PBB-P2.

Sarana/prasarana pendukung pengelolaan PBB-P2 harus disediakan secara lengkap. Tujuannya untuk menyimpan basis data secara aman dan dapat memberikan pelayanan dengan lebih baik kepada wajib pajak. Sarana/prasarana yang harus diwujudkan yaitu:

(1) Ruang pelayanan, server, dan ruang olah data yang compatibel agar memberikan kenyamanan bagi petugas PBB-P2 untuk bekerja dan memberikan pelayanan yang maksimal;

(2) Server yang dimiliki BPPKAD Kabupaten Blora saat ini hanya 2, yaitu 1 untuk billing pembayaran dan 1 lainnya untuk basis data PBB-P2. Diperlukan 1 lagi server PBB-P2 sebagai penyimpan data cadangan apabila server utama mengalami kerusakan atau gangguan virus;

(3) Mesin pencetak peta atau printer berukuran A0, kurang efektif bagi petugas desa/kelurahan. Perlu disediakan printer peta ukuran A3 sehingga tidak terlalu besar, tetapi dapat memuat gambar peta secara komplit;

(4) Perlu pengadaan mobil kas keliling, saat ini yang tersedia hanya 1 unit dengan jadwal yang terbagi dalam 16 kecamatan dan 295 desa/kelurahan. Selanjutnya diperlukan tambahan 3 unit mobil kas keliling untuk dibagi tiap 4 kecamatan agar lebih rutin menjemput setoran dari petugas desa/kelurahan pada tiap wilayah.

(5) Sebagai sarana pendataan di wilayah yang sulit, perlu pengadaan alat moderen untuk membantu kegiatan identifikasi lokasi objek pajak, misalnya pengadaan drone.

Indikator keberhasilan:

terwujudnya kemudahan bagi petugas untuk melaksanakan pengelolaan PBB-P2 dan memberikan pelayanan prima kepada wajib pajak.

\subsection{Acting}

Lindgren dan Bandhold (2003:99) menyatakan bahwa tahap acting bukan merupakan gambaran implementasi dari strategi yang telah dipilih pada tahap sebelumnya. Tetapi tahap acting adalah tindak lanjut setelah perumusan scenario planning, yaitu memonitor perubahan kondisi dan mendefinisikan proses untuk mengamati perubahan yang terjadi akibat dari 
pelaksanaan strategi yang telah dipilih. Pada pengelolaan PBB-P2, indikator untuk mengamati perubahan yang terjadi sebagai keberhasilan dari pelaksanaan misi, yaitu:

(1) Tersedianya basis data yang lengkap, akurat, dan objektif sesuai kondisi terkini, baik data atribut maupun data peta;

(2) Meningkatnya kepatuhan wajib pajak, hal ini terlihat dari menurunnya jumlah tunggakan pajak dan realisasi pajak $100 \%$;

(3) Tidak ada lagi permohonan keberatan dan keringanan dari wajib pajak karena kesalahan data;

(4) Meningkatnya responsifitas petugas dalam memberikan pelayanan kepada wajib pajak;

(5) Permohonan wajib pajak secara manual berkurang karena lebih banyak yang memanfaatkan pelayanan secara online;

(6) Terjalinnya koordinasi yang baik dengan unit organisasi lain maupun private sector;

(7) Pelayanan optimal didukung tenaga profesional yang kredibel sehingga tidak ada lagi complain dari wajib pajak;

(8) Tersedianya informasi yang up to date dan mudah diakses oleh masyarakat.

\section{PENUTUP}

\section{Simpulan}

Hasil penelitian tentang pengelolaan PBB-P2 di Kabupaten Blora menyimpulkan bahwa pendapatan Pajak Daerah sektor PBB-P2 belum dikelola secara optimal oleh BPPKAD Kabupaten Blora. Penilaian secara individual dilaksanakan terhadap objek khusus sebanyak 13 objek. Berdasarkan penelitian, masih banyak objek pajak lain yang belum dilakukan pendataan dan penilaian, sehingga dapat disimpulkan bahwa upaya updating data telah dilakukan tetapi belum secara maksimal karena adanya beberapa hambatan. Salah satu hambatan tersebut adalah kurangnya tenaga penilai PBB-P2. BPPKAD belum pernah melaksanakan upaya pemetaan objek PBB-P2 sejak pelimpahan dari pajak pusat menjadi pajak daerah. Pemetaan ini dalam arti mengklasifikasikan ulang wilayah yang harus ditingkatkan NJOP-nya sesuai dengan perkembangan wilayah. Perkembangan dimaksud berupa tanah kosong atau sawah yang telah berubah alih fungsi menjadi kawasan perumahan, hotel, maupun industri.

\section{Saran}

Berdasarkan simpulan penelitian, peneliti memberikan saran sebagai berikut:

Memprioritaskan implementasi misi dan strategi perencanaan pengelolaan PBB-P2 di Kabupaten Blora sesuai Skenario B (komitmen pemerintah + , pertumbuhan ekonomi + ), yaitu: a) Melakukan identifikasi dan analisis transaksi jual beli dari sumber penjual atau pembeli secara langsung, pengembang perumahan, iklan di surat kabar maupun media massa online, serta data pembayaran Bea Perolehan Hak Atas Tanah dan Bangunan (BPHTB);

b) Melakukan analisis dan pemetaan NJOP bumi sesuai dengan tingkat perkembangan wilayah per zona, apabila perlu akan dibuat zona nilai tanah baru atau pemekaran zona;

c) Melakukan penilaian secara individual terhadap objek pajak khusus yang baru berdiri dan sudah beroperasi dengan harga material yang sudah disesuaikan;

d) Menggandakan basis data untuk disimpan di harddisk yang terpisah sebagai langkah pengamanan dari virus komputer;

e) Melakukan editing peta lokasi sesuai kondisi terbaru, sehingga memudahkan untuk mengidentifikasi sebuah lokasi atau melakukan analisis NJOP bumi;

f) Mengikutsertakan pegawai Pemerintah Kabupaten Blora yang masih memenuhi syarat dari aspek usia maupun kepangkatan untuk menempuh perkuliahan di bidang penilaian PBB-P2 atau penilaian properti;

g) Aktif berkoordinasi dengan unit organisasi atau instansi terkait untuk transfer data atau informasi;

h) Meningkatkan kualitas pelayanan publik dengan membangun pelayanan online atau berbasis internet;

i) Penyediaan mobil kas keliling yang aktif bersiaga di tiap kecamatan;

j) Penyediaan sarana/prasarana kantor pendukung pengelolaan PBB-P2.

\section{DAFTAR PUSTAKA}

Direktorat Jenderal Pajak, t.t. Undang-Undang Republik Indonesia Nomor 28 Tahun 2009 tentang Pajak Daerah dan Retribusi Daerah. Jakarta.

Halim, Abdul, 2016. Manajemen Keuangan Sektor Publik: Problematika Penerimaan dan Pengeluaran Pemerintah. Jakarta: Salemba Empat.

Hartoyo, Harry dan Supardi, Untung, 2010. Membedah Pengelolaan Administrasi PBB dan BPHTB. Jakarta: Mitra Wacana Media.

Kementerian Keuangan Republik Indonesia, t.t. Peraturan Menteri Dalam Negeri Nomor 13 Tahun 2006 tentang Pedoman Pengelolaan Keuangan Daerah. Jakarta. 
Lindgren, Mats dan Bandhold, Hans, 2003. Scenario Planning: The Link Between Future and Strategy. New York: Palgrave Macmillan.

Miles, Matthew B., Huberman, A.Michael, dan Saldana, Johnny, 2014. Qualitative Data Analysis. California: Sage Publications Inc.

Pemerintah Kabupaten Blora, Peraturan Bupati Blora Nomor 26 Tahun 2013 tentang Ketentuan Pelaksanaan Peraturan Daerah Kabupaten Blora Nomor 6 Tahun 2012 Tentang Pajak Bumi dan Bangunan Perdesaan dan Perkotaan. Blora.

Pemerintah Kabupaten Blora, Peraturan Daerah Kabupaten Blora Nomor 6 Tahun 2012 tentang Pajak Bumi dan Bangunan Perdesaan dan Perkotaan. Blora.

Pemerintah Kabupaten Blora, Peraturan Daerah Kabupaten Blora Nomor 13 Tahun 2016 tentang Anggaran Pendapatan dan Belanja Daerah Tahun Anggaran 2017. Blora. 